Article

\title{
Effect of Airtightness on Thermal Loads in Legacy Low-Income Housing
}

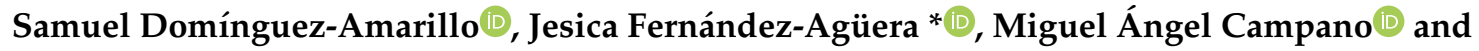 \\ Ignacio Acosta \\ Instituto Universitario de Arquitectura y Ciencias de la Construcción, Escuela Técnica Superior de Arquitectura, \\ Universidad de Sevilla, 41014 Sevilla, Spain; sdomin@us.es (S.D.-A.); mcampano@us.es (M.Á.C.); \\ iacosta@us.es (I.A.) \\ * Correspondence: jfernandezaguera@us.es
}

Received: 3 March 2019; Accepted: 29 April 2019; Published: 2 May 2019

check for updates

\begin{abstract}
Spain's high winter weather-associated death count, the second largest in Europe, can be attributed primarily to the low construction standards of its social housing, particularly the stock built prior to the entry into effect of the earliest statutory provisions on envelope quality. Hence, improving building envelopes to both reduce energy consumption and raise occupant comfort levels is important. Air leakage is one of the factors with the greatest impact on indoor comfort and domestic energy consumption. This study explores the sensitivity of energy consumption to that parameter in a series of types of social housing built between 1950 and 1979 in five Mediterranean climate zones. Demand in a total of 53 housing units located in 21 developments was simulated to that end. The findings show that air permeability has a significant effect on wintertime demand in the sample studied. Although the impact is greater in the more severe climates where it is estimated to be over $10 \mathrm{kWh} / \mathrm{m}^{2}$, it may also affect energy consumption in mild climates.
\end{abstract}

Keywords: airtightness; residential buildings; blower door test; air infiltration; southern Europe; energy demand

\section{Introduction}

Spain is the European country with the second-highest number of winter-related deaths [1]. That statistic is due primarily to poor construction standards, especially in low-income housing with no environmental control systems. Envelope airtightness or uncontrolled indoor-outdoor air exchange is one of the key variables in residential energy consumption and comfort.

The method most commonly accepted by the scientific community to assess airtightness is the blower door test. A number of studies have been conducted on airtightness in single-family homes in northern Europe [2-6] and the United States [7-9] over the last three decades. It has also been an emerging field of research over the last 10 years in southern Europe, Spain included [10-14], where the Infiles research project [15] presently underway has been enlarging the country's airtightness database [16-20] using a standardised measuring protocol to ensure comparability of the findings.

Most of the literature quantifying the energy demand associated with infiltration reports on conditions in northern Europe, where the energy impact of air infiltration on heating demand is estimated to be in the order of $10 \mathrm{kWh} / \mathrm{m}^{2}$ in moderately cold regions (2500 degree-days at $20^{\circ} \mathrm{C}$ ) [21]. This question has been scantly studied in Spain, however, although some research has been conducted in mild [22] and continental-like climates. In one study, the energy impact of infiltrations was assessed using a simplified model (Equation (1)) based on the degree-day concept that relates the mean outdoor to the indoor comfort temperature $\left(21^{\circ} \mathrm{C}\right.$ for heating and $25^{\circ} \mathrm{C}$ for cooling). While actual energy consumption depends on the specific temperature prevailing in any given dwelling, this theoretical 
model can be used to determine the impact of air inflow, specific air capacity, and the indoor-outdoor temperature difference on energy demand in the locations where the tests are performed [18]. Meiss and Feijó [23], analysing 13 housing units in northern Spain, were the first to address the subject from an energy perspective. They estimated the impact of infiltration on energy demand in housing built on the existing technical building code [24] to range from $10.5 \%$ to $27.4 \%$; in units constructed under the former code [25], from $21.9 \%$ and $27 \%$; and in those dating prior to 1979 but retrofitted by their occupants, from $11.3 \%$ to $13 \%$ :

$$
\operatorname{Qinf}=C p \cdot G t \cdot V \inf
$$

where

Qinf is the annual air infiltration-induced energy loss (kWh/year) for heating $\operatorname{Qinf}_{H}$ and cooling Qinf $f_{C}$ expressed per unit area;

$C p$ is the specific heat capacity of air, assumed to be $0.34 \mathrm{Wh} / \mathrm{m}^{3} \cdot \mathrm{K}$;

$\mathrm{Gt}$ is the annual degree-days (kKh/year), assuming a baseline comfort temperature of $21^{\circ} \mathrm{C}$ for heating $\left(G t_{\mathrm{H}}\right)$ and of $25^{\circ} \mathrm{C}$ for cooling $\left(G t_{\mathrm{C}}\right)$; and

Vinf is the air leakage rate $\left(\mathrm{m}^{3} / \mathrm{h}\right)$.

The conclusion reached was that losses attributable to air change are relatively greater in multifamily than in single-family detached housing and are becoming more important in better insulated buildings [26].

This study aims primarily to analyse the vulnerability to air leakage of the envelopes of social housing built prior to entry in effect CT79, Spain's first legislation on the subject [24]. This aspect is very important for the cost-optimal analysis applications in Europe since the Energy Performance of Buildings Directive (EPBD) recast [27].

\section{Materials and Methods}

\subsection{Characterisation of Social Housing and Sampling}

A study of social housing typologies and characteristics in southern Spain [28-30] laid the ground for stratified random sampling and the definition of a sample on which to conduct building envelope airtightness tests and energy demand simulation. The attribute defined for stratification was the one deemed to have the greatest potential to induce differences [17,31] in the construction solutions adopted for building envelopes: area-dependent climate [29]. The parameters involved were regarded to possibly play a role in determining envelope performance, once the geometric parameters routinely used and regional construction particularities were identified and further to the characteristics determined for the overall and regional housing stocks. A total of 21 multi-owned housing developments were selected as particularly representative of low-income buildings. The location, year of construction and morphological characteristics of these developments are given in Table 1, a description of their envelopes in Table 2, and their geometry in Figure 1.

The simulations were run using the envelopes found to be specific to each façade model and building type in earlier analysis and classification studies [29,30]. The representative models identified included three types of façade enclosures, two variations on the F1 model and one F2 model, as listed in Table 2. Envelopes were defined on the grounds of their specific mass, constructional composition, energy parameters of the materials and reflectivity and emissivity of the outer façade surface. The variability among enclosures was narrow, for most of the housing built in the period fluctuated between several of those established, as discussed in [29]. The wider range of variation identified in the roofs was factored into the definitions of the building energy models. Briefly, the procedure involved differentiating the buildings on the grounds of their constructional characteristics, morphology and geometry (opening-to-blank wall, wall-to-floor ratios and similar), location and airtightness to mirror actual behaviour as accurately as possible. 
Table 1. Year, climate zone and morphological characteristics of sample dwellings.

\begin{tabular}{|c|c|c|c|c|c|c|c|c|}
\hline \multirow{2}{*}{ ID } & \multirow{2}{*}{ Year } & \multirow{2}{*}{ Climate Zone } & \multirow{2}{*}{ City } & \multirow{2}{*}{$\begin{array}{c}\text { Floor Area } \\
\left(\mathrm{m}^{2}\right)\end{array}$} & \multirow{2}{*}{$\begin{array}{c}\text { Volume } \\
\left(\mathrm{m}^{3}\right)\end{array}$} & \multirow{2}{*}{$\begin{array}{c}\text { Façade Area } \\
\left(\mathrm{m}^{2}\right)\end{array}$} & \multirow{2}{*}{$\begin{array}{c}\text { Window Area } \\
\left(\mathrm{m}^{2}\right)\end{array}$} & \multirow{2}{*}{ Façade Type } \\
\hline & & & & & & & & \\
\hline P01 & 1954 & $\mathrm{~A} 3$ & Cádiz & 62 & 155 & 44 & 10 & 1 \\
\hline P02 & 1968 & $\mathrm{~A} 3$ & Málaga & 51 & 131 & 34 & 9 & 2 \\
\hline P03 & 1971 & $\mathrm{~A} 3$ & Cádiz & 67 & 161 & $37-53$ & 8 & 2 \\
\hline P04 & 1972 & A3 & Cádiz & 64 & 160 & 38 & 9 & 2 \\
\hline P05 & 1974 & A3 & Cádiz & 55 & 138 & 40 & 8 & 2 \\
\hline P06 & 1976 & A3 & Málaga & 106 & 263 & 73 & 14 & 2 \\
\hline P07 & 1978 & A3 & Málaga & 51 & 127 & 59 & 10 & 2 \\
\hline P08 & 1966 & A4 & Huelva & 46 & 105 & 38 & 6 & 2 \\
\hline P09 & 1969 & A4 & Huelva & 57 & 144 & 58 & 14 & 2 \\
\hline P10 & 1970 & A4 & Huelva & 95 & 212 & 51 & 13 & 2 \\
\hline P11 & 1961 & A4 & Huelva & 45 & 109 & 35 & 5 & 1 \\
\hline P12 & 1951 & B4 & Seville & 46 & 127 & 38 & 7 & 1 \\
\hline P13 & 1963 & B4 & Seville & 58 & 140 & 38 & 6 & 1 \\
\hline P14 & 1964 & B4 & Seville & $59-73$ & 161-199 & 79-92 & 09-10 & 2 \\
\hline P15 & 1965 & B4 & Seville & 49 & 110 & 49 & 13 & 2 \\
\hline P16 & 1970 & B4 & Córdoba & 53 & 127 & 36 & 9 & 2 \\
\hline P17 & 1973 & B4 & Córdoba & 64 & 159 & 43 & 10 & 2 \\
\hline P18 & 1978 & B4 & Seville & 72 & 179 & 65 & 19 & 2 \\
\hline P19 & 1959 & C3 & Granada & 65 & 162 & 67 & 12 & 1 \\
\hline P20 & 1964 & C4 & Jaén & 56 & 143 & 33 & 8 & 1 \\
\hline P21 & 1967 & C4 & Jaén & 55 & 136 & 38 & 7 & 2 \\
\hline
\end{tabular}

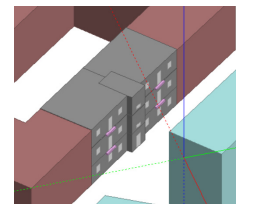

P01

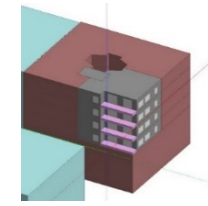

P06

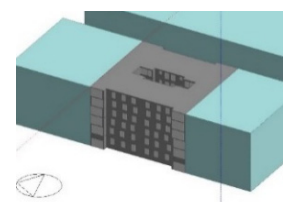

P011

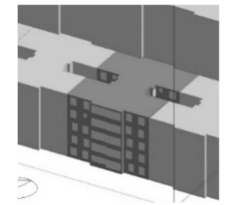

P016

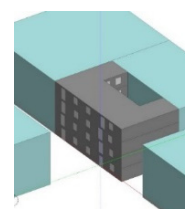

P021

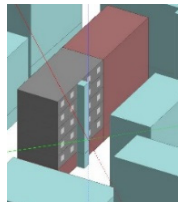

P02

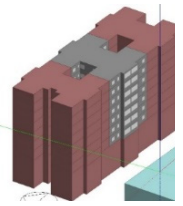

P07

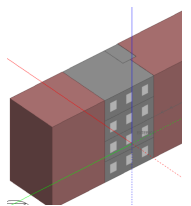

P012

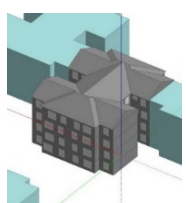

P017

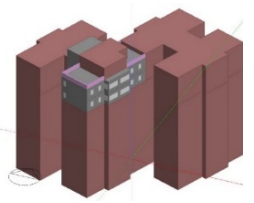

P03

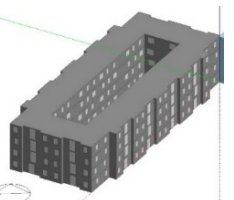

P08

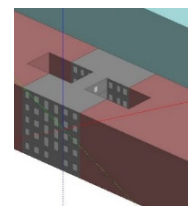

P013

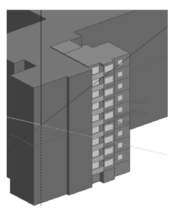

P018

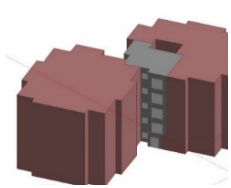

P04

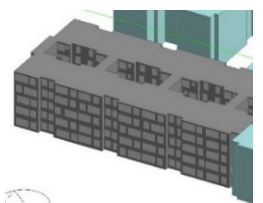

P09

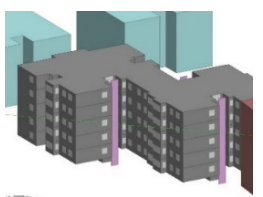

P014

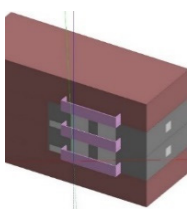

P019

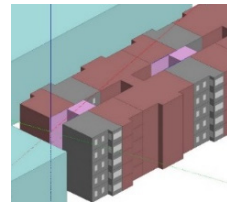

P05

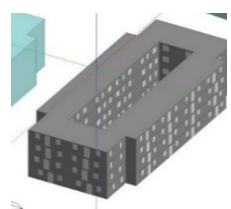

P010

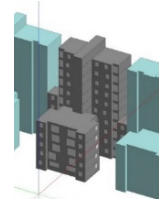

P015

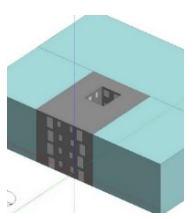

P020

Figure 1. Energy models in the sample studied (Design Builder software). 
Table 2. Envelope characteristics.

\begin{tabular}{|c|c|c|c|}
\hline & Composition & $\begin{array}{l}\text { Transmittance } U \\
\left(\mathrm{~W} /\left(\mathrm{m}^{2} \mathrm{~K}\right)\right)\end{array}$ & Solar Factor \\
\hline \multirow[t]{2}{*}{ Façades } & $\begin{array}{l}\text { F1: } 1.5 \mathrm{~cm} \text { cement mortar; } 6 \text { inch }(11.5 \mathrm{~cm}) \text { or } 12 \text { inch }(23 \mathrm{~cm}) \text { perforated } \\
\text { metric brick; } 1 \mathrm{~cm} \text { plaster surfacing }\end{array}$ & $1.56-1.29$ & \\
\hline & $\begin{array}{c}\text { F2: } 1.5 \mathrm{~cm} \text { cement mortar; } 6 \text { inch }(11.5 \mathrm{~cm}) \text { perforated metric brick; } 3 \mathrm{~cm} \\
\text { to } 5 \mathrm{~cm} \text { non-ventilated air chamber; } 5 \mathrm{~cm} \text { hollow brick; } 1 \mathrm{~cm} \\
\text { plaster surfacing }\end{array}$ & 1.39 & \\
\hline Partitions & $\begin{array}{c}1 \mathrm{~cm} \text { plaster surfacing; } 6 \text { inch }(11.5 \mathrm{~cm}) \text { perforated metric brick; } 1 \mathrm{~cm} \\
\text { plaster surfacing }\end{array}$ & 2.05 & \\
\hline Floors/ceilings & $\begin{array}{l}3 \mathrm{~cm} \text { tile flooring; } 2 \mathrm{~cm} \text { cement mortar; } 25 \mathrm{~cm} \text { brick infill between } \\
\text { one-way beams; } 1.5 \mathrm{~cm} \text { plaster surfacing }\end{array}$ & 1.58 & \\
\hline Windows & Aluminium frame with no thermal bridge break; single $6 \mathrm{~mm}$ glass pane & 5.81 & 0.82 \\
\hline
\end{tabular}

\subsubsection{Location and Climate}

Although the region of southern Spain known as Andalusia has a Mediterranean climate, several sub-zones can be identified, from areas characterised by cold winters (Granada) to others with temperate weather year-round (Almería). More detailed information on the climate zones envisaged in national energy performance legislation is given in [32]. The present study covered the five climate zones most representative of Andalusia, ranging from very mild (zone A) to cold (zone C) winters and warm (zone 3) to hot (zone 4) summers. Separate predictive models were developed for each climate zone. The mean, maximum and minimum temperatures on record for each zone are given in Table 3.

Table 3. Mean (T), maximum (TM) and minimum (Tm) temperature by climate zone.

\begin{tabular}{|c|c|c|c|c|c|c|c|c|c|c|c|c|c|}
\hline & Month & 1 & 2 & 3 & 4 & 5 & 6 & 7 & 8 & 9 & 10 & 11 & 12 \\
\hline \multirow{4}{*}{ A3 } & $\mathrm{T}\left({ }^{\circ} \mathrm{C}\right)$ & 12.1 & 12.9 & 14.7 & 16.3 & 19.3 & 23.0 & 25.5 & 26.0 & 23.5 & 19.5 & 15.7 & 13.2 \\
\hline & $\mathrm{TM}\left({ }^{\circ} \mathrm{C}\right)$ & 16.8 & 17.7 & 19.6 & 21.4 & 24.3 & 28.1 & 30.5 & 30.8 & 28.2 & 24.1 & 20.1 & 17.5 \\
\hline & $\operatorname{Tm}\left({ }^{\circ} \mathrm{C}\right)$ & 7.4 & 8.2 & 9.8 & 11.1 & 14.2 & 18.0 & 20.5 & 21.1 & 18.8 & 15.0 & 11.3 & 8.9 \\
\hline & $\mathrm{T}\left({ }^{\circ} \mathrm{C}\right)$ & 12.6 & 13.3 & 15.1 & 17.0 & 19.7 & 23.5 & 26.1 & 26.7 & 24.2 & 20.4 & 16.4 & 13.8 \\
\hline \multirow{3}{*}{ A4 } & $\mathrm{TM}\left({ }^{\circ} \mathrm{C}\right)$ & 16.9 & 17.6 & 19.6 & 21.4 & 24.1 & 27.9 & 30.5 & 31.0 & 28.4 & 24.5 & 20.5 & 17.9 \\
\hline & $\operatorname{Tm}\left({ }^{\circ} \mathrm{C}\right)$ & 8.3 & 9.0 & 10.6 & 12.5 & 15.3 & 18.9 & 21.7 & 22.4 & 20.0 & 16.3 & 12.3 & 9.6 \\
\hline & $\mathrm{T}\left({ }^{\circ} \mathrm{C}\right)$ & 10.9 & 12.5 & 15.6 & 17.3 & 20.7 & 25.1 & 28.2 & 27.9 & 25.0 & 20.2 & 15.1 & 11.9 \\
\hline \multirow[t]{3}{*}{$\mathrm{B} 4$} & $\mathrm{TM}\left({ }^{\circ} \mathrm{C}\right)$ & 16.0 & 18.1 & 21.9 & 23.4 & 27.2 & 32.2 & 36.0 & 35.5 & 31.7 & 26.0 & 20.2 & 16.6 \\
\hline & $\operatorname{Tm}\left({ }^{\circ} \mathrm{C}\right)$ & 5.7 & 7.0 & 9.2 & 11.1 & 14.2 & 18.0 & 20.3 & 20.4 & 18.2 & 14.4 & 10.0 & 7.3 \\
\hline & $\mathrm{T}\left({ }^{\circ} \mathrm{C}\right)$ & 6.5 & 8.5 & 11.4 & 13.3 & 17.2 & 22.3 & 25.3 & 24.8 & 21.1 & 16.0 & 10.6 & 7.6 \\
\hline \multirow[t]{3}{*}{$\mathrm{C} 3$} & $\mathrm{TM}\left({ }^{\circ} \mathrm{C}\right)$ & 13.0 & 15.4 & 19.0 & 20.6 & 25.0 & 31.0 & 34.8 & 34.2 & 29.4 & 23.2 & 17.0 & 13.4 \\
\hline & $\operatorname{Tm}\left({ }^{\circ} \mathrm{C}\right)$ & 0.0 & 1.6 & 3.8 & 6.0 & 9.4 & 13.6 & 15.7 & 15.5 & 12.8 & 8.7 & 4.2 & 1.7 \\
\hline & $\mathrm{T}\left({ }^{\circ} \mathrm{C}\right)$ & 8.6 & 10.3 & 13.1 & 14.5 & 18.2 & 23.7 & 27.6 & 26.9 & 22.8 & 17.9 & 12.3 & 9.5 \\
\hline \multirow[t]{2}{*}{$\mathrm{C} 4$} & $\mathrm{TM}\left({ }^{\circ} \mathrm{C}\right)$ & 12.1 & 14.0 & 17.4 & 19.0 & 23.2 & 29.4 & 33.7 & 32.9 & 27.7 & 21.9 & 15.7 & 12.8 \\
\hline & $\operatorname{Tm}\left({ }^{\circ} \mathrm{C}\right)$ & 5.1 & 6.6 & 8.9 & 10.0 & 13.3 & 18.1 & 21.4 & 21.0 & 17.8 & 13.8 & 8.9 & 6.3 \\
\hline
\end{tabular}

\subsubsection{Airtightness}

Dwelling envelope airtightness was measured with the standard blower door test implemented as described in [12]. The tests were conducted for an airtightness value of $50 \mathrm{~Pa}$ with a Minneapolis Blower Door Model 4 facility featuring $\pm 3 \%$ accuracy and an operating range of $25 \mathrm{~m}^{3} \cdot \mathrm{h}^{-1}$ to $7800 \mathrm{~m}^{3} \cdot \mathrm{h}^{-1}$. Measurements were taken at pressures ranging from $20 \mathrm{~Pa}$ to $70 \mathrm{~Pa}$ at $5 \mathrm{~Pa}$ intervals further to the procedure described in the Spanish and European standard UNE EN 13829:2002 [33]. Airtightness was measured at an infiltration rate of $50 \mathrm{~Pa}$ in a total of 53 units located in the 21 developments studied. The mean $V_{50}, n_{50}$ and $q_{50}$ values and respective standard deviations listed in Table 4 are discussed in greater detail in [34].

Blower door test values were used to calibrate the models and determine the mean value for subsequent analyses. Vinf was calculated from the test values at a pressure difference of $50 \mathrm{~Pa}$. As the latter do not measure actual dwelling air leakage, however, they had to be converted to equivalent real air flows. Estimating actual infiltration is a complex task, given that wind and temperature conditions throughout the year are difficult to foresee and the test does not deliver precise air leakage data.

The Persily-Kronvall procedure [35], a simple, widely used model, assumes that permeability at $50 \mathrm{~Pa}$ is linearly related to mean yearly infiltration (Equation (2)). Sherman [36] developed 
another simple approach (Equation (3)) from the LBL infiltration model for the annual infiltration rate of detached houses in North America, introducing $N$, a correlation factor found as the product of factors representing climate zone, wind shielding, house height and crack size. According to extensive measuring undertaken in several European countries as reported by Dubrul in 1988 [26], the denominator in Equation (3) ranges from 10 to 30, depending on building type, wind conditions and leakage distribution.

Here, the value assumed was 20 because the sample consisted of multifamily housing with uniformly distributed leakage, intermediate-sheltered exposure and a mean wintertime meteorological wind speed of under $4 \mathrm{~m} / \mathrm{s}$.

$$
\begin{aligned}
& n_{50}=\frac{V_{50}}{20 V} . \\
& A C H=\frac{n_{50}}{N}
\end{aligned}
$$

where:

$V$ is the internal air volume $\left(\mathrm{m}^{3}\right)$;

$V_{50}$ is the air leakage rate at $50 \mathrm{~Pa}\left(\mathrm{~m}^{3} / \mathrm{h}\right)$;

$\mathrm{n}_{50}$ is the air change rate at $50 \mathrm{~Pa}\left(\mathrm{~h}^{-1}\right)$;

$A C H$ is air change rate per hour at standard pressure $\left(\mathrm{m}^{3} / \mathrm{h}\right)$;

$N$ is a correlation factor.

Table 4. Blower door test findings for $V_{50}, n_{50}$ and $q_{50}$ (mean and standard deviation for each development).

\begin{tabular}{rccccccc}
\hline & Sample & \multicolumn{2}{c}{$V_{\mathbf{5 0}}\left(\mathbf{m}^{\mathbf{3}} / \mathbf{h}\right)$} & \multicolumn{2}{c}{$\boldsymbol{n}_{\mathbf{5 0}}\left(\mathrm{h}^{-\mathbf{1}}\right)$} & \multicolumn{2}{c}{$\boldsymbol{q}_{\mathbf{5 0}}\left(\mathrm{m}^{\mathbf{3}} / \mathrm{hm}^{\mathbf{2}}\right)$} \\
\hline $\mathbf{1}$ & No. Flats & Mean & SD & Mean & SD & Mean & SD \\
$\mathbf{2}$ & 4 & 758 & 73.41 & 5.13 & 0.39 & 17.23 & 1.67 \\
$\mathbf{3}$ & 3 & 1.038 & 44.58 & 7.93 & 0.34 & 30.53 & 1.31 \\
$\mathbf{4}$ & 3 & 954 & 89.82 & 5.73 & 0.57 & 21.20 & 2.00 \\
$\mathbf{5}$ & 4 & 1054 & 198.87 & 6.58 & 1.01 & 27.74 & 5.23 \\
$\mathbf{6}$ & 4 & 951 & 142.52 & 6.89 & 1.03 & 23.78 & 3.56 \\
$\mathbf{7}$ & 1 & 1025 & 0 & 3.89 & 0 & 14.04 & 0 \\
$\mathbf{8}$ & 1 & 1675 & 0 & 13.14 & 0 & 28.39 & 0 \\
$\mathbf{9}$ & 3 & 807 & 296.11 & 7.68 & 2.82 & 21.24 & 7.79 \\
$\mathbf{1 0}$ & 2 & 1053 & 44 & 7.16 & 0.16 & 18.16 & 0.76 \\
$\mathbf{1 1}$ & 2 & 651 & 16 & 3.01 & 0.13 & 12.76 & 0.31 \\
$\mathbf{1 2}$ & 1 & 1277 & 0 & 11.62 & 0 & 36.49 & 0 \\
$\mathbf{1 3}$ & 1 & 1294 & 0 & 10.12 & 0 & 34.05 & 0 \\
$\mathbf{1 4}$ & 3 & 880 & 23.51 & 6.24 & 0.54 & 23.16 & 0.62 \\
$\mathbf{1 5}$ & 4 & 1184 & 440.68 & 7.32 & 1.92 & 14.27 & 5.31 \\
$\mathbf{1 6}$ & 3 & 1040 & 174.17 & 9.48 & 1.58 & 21.22 & 3.55 \\
$\mathbf{1 7}$ & 2 & 1564 & 139 & 12.3 & 1.09 & 43.44 & 3.86 \\
$\mathbf{1 8}$ & 1 & 1876 & 0 & 11.8 & 0 & 43.63 & 0 \\
$\mathbf{1 9}$ & 1 & 2624 & 0 & 14.68 & 0 & 40.37 & 0 \\
$\mathbf{2 0}$ & 2 & 830 & 50 & 5.11 & 0.31 & 12.39 & 0.75 \\
$\mathbf{2 1}$ & 4 & 925 & 371.56 & 6.46 & 2.59 & 28.03 & 11.26 \\
Mean & 4 & 929 & 226.03 & 6.8 & 1.65 & 24.45 & 5.95 \\
\hline $\mathbf{2}$ & & 985 & 154 & 7.5 & 1.04 & 25.55 & 2.57 \\
\hline
\end{tabular}

\subsection{Simulation}

All simulations were conducted with three levels of airtightness: the airtightness measured for each case plus building leakage rates of $n_{50}=0.2 \mathrm{~h}^{-1}$ and $n_{50}=1 \mathrm{~h}^{-1}$. Sensitivity analysis simulations were conducted for 53 flats located in 21 developments, applying their actual exposure to wind conditions (Figure 1). Most of the cases involved sheltered conditions, the type most commonly found in Spain because multifamily dwellings are located primarily in town/city centres where they are surrounded by trees and other buildings. Empirical leakage distribution data were used to calibrate the models.

Building energy assessments were performed for the three airtightness values using Design Builder Essentials software (5.0.2.003) which delivered daily, monthly and yearly demand data for all the case studies using Equation (4) (EN12831 [37]): 


$$
A C H=2 \cdot V \cdot n_{50} \cdot \tau \cdot \varepsilon
$$

where

$A C H$ is the air flow at standard pressure $\left(\mathrm{m}^{3} / \mathrm{h}\right)$;

$n_{50}$ is the air change rate at $50 \mathrm{~Pa}\left(\mathrm{~h}^{-1}\right)$;

$V$ is the indoor air volume $\left(\mathrm{m}^{3}\right)$;

$\tau$ is the wind exposure class (coefficient), determined from the façade exposure in each zone; and $\varepsilon$ is the building height class (coefficient).

An initial load analysis was performed for a mean air change rate per hour (ACH) of $0.35 \mathrm{~h}^{-1}$ to establish the infiltration load component in the energy balance during cooling and heating periods. The summation of the heat gains in summer and the heat loss in winter attributed to leakage was used to find the mean by climate zone for the developments comprising the sample. The $n_{50}$ values from $0.2 \mathrm{~h}^{-1}$ to $1 \mathrm{~h}^{-1}$ were used to develop the equations relating energy demand to $\mathrm{n}_{50}$ in the five climate zones in Andalusia.

\subsubsection{Operating Profiles}

The operating conditions (Table 5) used to simulate the housing units were drawn from the basic procedure for certifying building energy performance in effect in Spain and the energy savings requirements laid down in the country's technical building code (Annex C, basic document HE: Gobierno de España, 2013 [25]). Those texts define the values for the following indoor parameters: target and control temperature, occupancy, indoor loads, lighting and ventilation.

Table 5. Operating conditions set out in the basic procedure for certifying building energy performance in effect in Spain and the energy savings requirements defined in its technical building code.

\begin{tabular}{|c|c|c|c|c|c|}
\hline \multirow{2}{*}{ Item } & \multirow{2}{*}{ Value } & \multicolumn{4}{|c|}{ Time of Day } \\
\hline & & Winter & & Summer & \\
\hline \multirow{5}{*}{ Occupancy } & \multirow{5}{*}{$17.8 \mathrm{~m}^{2} /$ person } & 00:00 to $07: 00$ & $100 \%$ & 00:00 to $07: 00$ & $100 \%$ \\
\hline & & $07: 00$ to $16: 00$ & $25 \%$ & $07: 00$ to $16: 00$ & $25 \%$ \\
\hline & & $16: 00$ to $23: 00$ & $50 \%$ & $16: 00$ to $23: 00$ & $50 \%$ \\
\hline & & Weekends and holidays: & & Weekends 00:00 to $24: 00$ & 100 \\
\hline & & $00: 00$ to $24: 00$ & $50 \%$ & Holidays 00:00 to 24:00 & $0 \%$ \\
\hline \multirow{5}{*}{$\begin{array}{l}\text { Appliances and } \\
\text { lighting }\end{array}$} & \multirow{5}{*}{$4.44 \mathrm{~W} / \mathrm{m}^{2}$} & 00:00 to $08: 00$ & $10 \%$ & 00:00 to $08: 00$ & $10 \%$ \\
\hline & & $08: 00$ to $19: 00$ & $30 \%$ & $08: 00$ to $19: 00$ & $30 \%$ \\
\hline & & $19: 00$ to $20: 00$ & $50 \%$ & $19: 00$ to $20: 00$ & $50 \%$ \\
\hline & & $20: 00$ to $23: 00$ & $100 \%$ & $20: 00$ to $23: 00$ & $100 \%$ \\
\hline & & $23: 00$ to $24: 00$ & $50 \%$ & $23: 00$ to $24: 00$ & $50 \%$ \\
\hline \multirow{2}{*}{ Ventilation } & \multirow{2}{*}{$4 \mathrm{~h}^{-1}$} & \multirow{2}{*}{$00: 00$ to $24: 00$} & \multirow{2}{*}{$0 \%$} & 00:00 to $08: 00$ & $100 \%$ \\
\hline & & & & 08:00 to $24: 00$ & $0 \%$ \\
\hline \multirow{5}{*}{ Air temperature } & \multirow{5}{*}{ Target } & $00: 00$ to $16: 00$ & - & 00:00 to $08: 00$ & \multirow{5}{*}{$26^{\circ} \mathrm{C}$} \\
\hline & & $16: 00$ to $23: 00$ & $20{ }^{\circ} \mathrm{C}$ & $08: 00$ to $23: 00$ & \\
\hline & & $23: 00$ to $24: 00$ & - & $23: 00$ to $24: 00$ & \\
\hline & & \multicolumn{2}{|c|}{ Winter: November to March } & & \\
\hline & & \multicolumn{2}{|c|}{ Summer: April to September } & & \\
\hline
\end{tabular}

Operating conditions and occupancy profiles varied with the month of the year and day of the week (weekday or weekend). Spanish legislation envisages night time ventilation of $4 \mathrm{~h}^{-1}$ in the summer months.

Winter was defined as the period from November to March and the rest of the year as summer. Given the importance of climate zone in infiltration-induced energy demand, all five zones were analysed.

The number of times the flats were ventilated, along with the duration and the time of day in winter and summer, were determined for these buildings [38]. The conclusion reached was that the ventilation rate in winter was very low- $0.0 \mathrm{~h}^{-1}$ to $0.1 \mathrm{~h}^{-1}$-because windows were opened only minimally in that season. This was supported by findings from a more extensive study conducted by Dubrul [26]. 


\subsubsection{Calibration}

The model was calibrated by comparing the values calculated to actual empirical data and adjusting for parameters such as airtightness, density and floor temperature as necessary further to the ASHRAE standard 14-2002 [39] specifications. The control flats were used both to determine thermal behaviour and calibrate the nodal model. Actual thermal and operational profiles were created by extracting hourly values for the indoor parameters as in [40].

Mean bias error (MBE) (Equations (5) and (6)) and the coefficient of variation for the root mean square error (CV/RMSE) (Equation (7)) were used to assess the differences between simulated and observed hourly data:

$$
\begin{gathered}
M B E=\frac{\sum_{i=1}^{N_{s}}\left(y_{i}-\hat{y}_{i}\right)}{\sum_{i=1}^{N_{s}} y_{i}} \\
\hat{Y}_{S}=\frac{\sum_{i=1}^{N_{s}} y_{i}}{N_{S}} \\
\operatorname{CVRMSE}_{(S)}=\frac{\sqrt{\sum_{i=1}^{N_{s}} \frac{\left(y_{i}-\hat{y}_{i}\right)^{2}}{N_{s}}}}{\hat{Y}_{S}}
\end{gathered}
$$

where

$y_{i}$ is the recorded data;

$\hat{y}_{i}$ is the simulated data;

$N_{S}$ is the sample size;

$\hat{Y}_{S}$ is the mean recorded data for the sample.

Calibration for model P13 during one week in winter is depicted by way of example in Figure 2, which compares the simulated to the monitored indoor temperature (and $\pm 0.5^{\circ} \mathrm{C}$ error). The $\mathrm{MBE}$ and CV/RMSE values for both lay within the range defined in ASHRAE 14-2002.

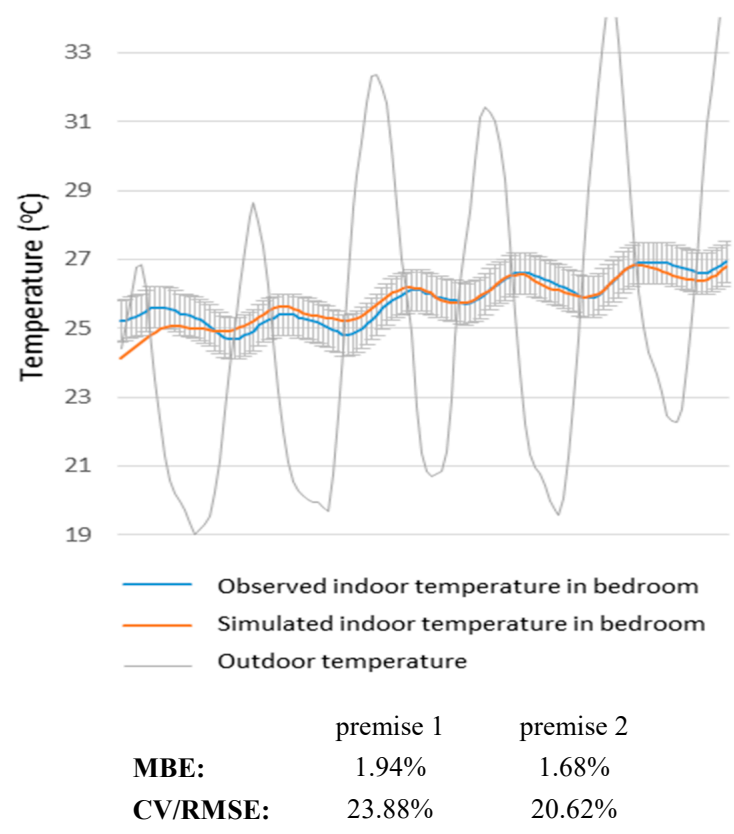

Figure 2. Comparison of simulated and observed indoor air temperatures $\left({ }^{\circ} \mathrm{C}\right)$ for model P13. 


\section{Results and Discussion}

The sensitivity of building energy performance to building airtightness is discussed below, analysing the response separately for heat gain or loss, i.e., in cooling or heating regimes.

\subsection{Overall Impact of Leakage on Energy Demand}

The simulated monthly demand values normalised to unit floor area for climate zone B4 graphed in Figure 3 show that heat loss in that zone was attributable more to infiltration than any other factor. Similar findings were observed for the other zones.

\begin{tabular}{ll|l|l|l|l|l|l|l|}
\hline & \\
\hline
\end{tabular}

Figure 3. Predicted heating demand by factor and month in climate zone $\mathrm{B} 4\left(\mathrm{ACH}=0.35 \mathrm{~h}^{-1}\right)$.

The demand values attributable to infiltration are graphed in Figure 4, normalised to unit floor area, for both the cold and warm seasons. One of the most prominent observations was that the effect of air infiltration was most intense in the winter and associated with heating needs. Leakage-related energy requirements in winter were from 10 to nearly 40 times higher than in summer.

Heating demand values associated with leakage rose with the severity of the cold season. The greatest negative balance recorded for all the models was observed in climate zone $\mathrm{C} 3$, with a mean of $-10.37 \mathrm{kWh} / \mathrm{m}^{2}$, nearly double the mean $-5.18 \mathrm{kWh} / \mathrm{m}^{2}$ to $-5.8 \mathrm{kWh} / \mathrm{m}^{2}$ observed for the regions with winter climate severity $\mathrm{A}$.

The summertime effect of leakage on demand was much smaller in absolute terms. As a rule, in summer, the negative night-time demand offset the positive daytime demand, lowering the net value or even generating a negative balance. That was observed in areas with milder summers (and night time outdoor temperatures normally lower than the indoor values), such as in climate zone A. The value of such offsets declined with the severity of summer heat (zone 4), with clearly positive balances in the B4 climate zone, for instance. 


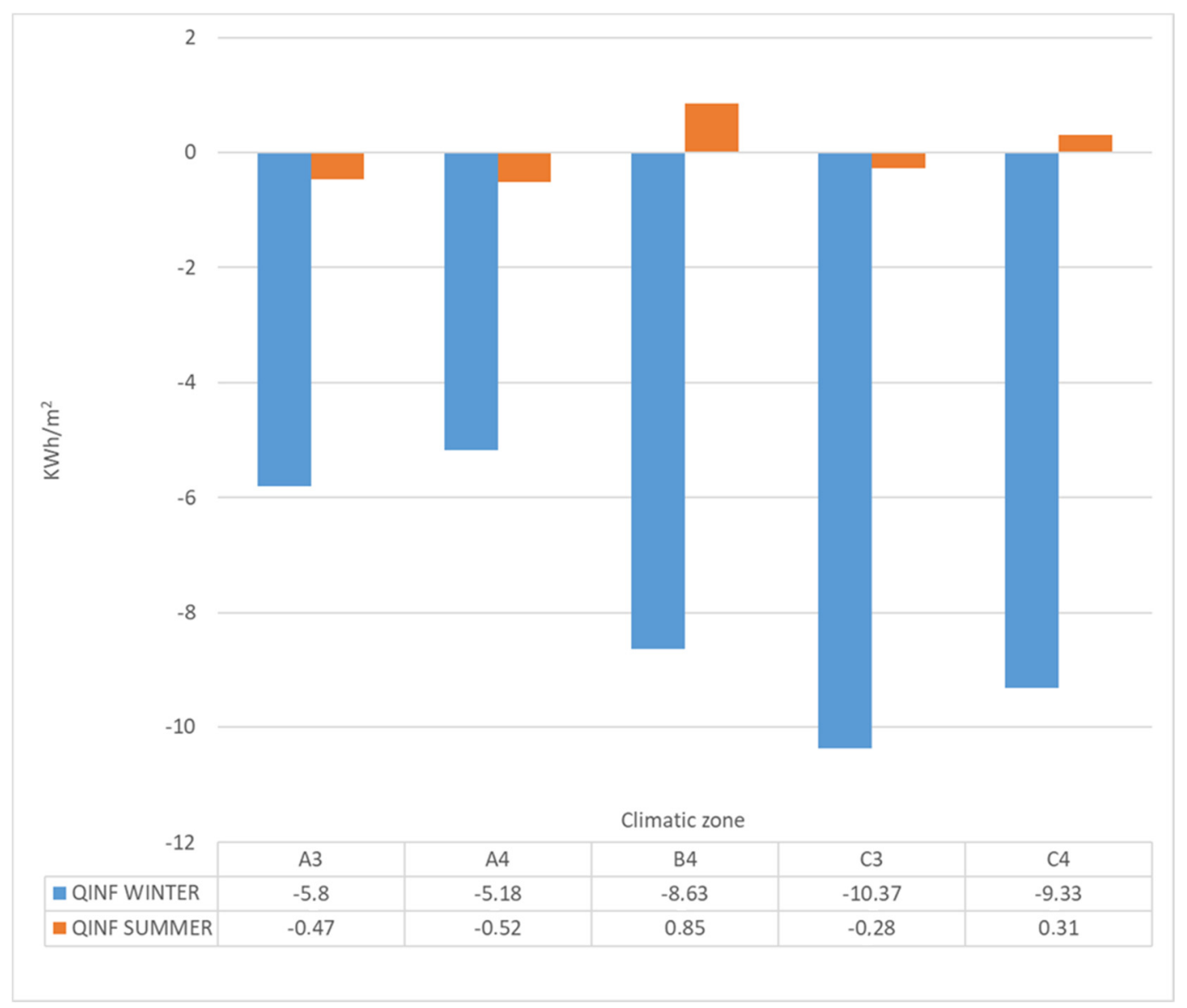

Figure 4. Predicted net demand attributable to infiltration in winter and summer (mean for the climate zones sampled, at $\mathrm{ACH}=0.35 \mathrm{~h}^{-1}$ ).

\subsection{Energy Demand Sensitivity to Envelope Airtightness}

The relative importance of leakage-mediated demand in housing is a variable in the formulation of their cooling/heating load structure. Generally speaking, the models used showed that housing with thermal envelopes best able to control heat flows were the ones that would be most sensitive to changes in air flow rates, i.e., the relative increase in the total load would tend to rise the most where transmission was weakest.

The slope of the curve for predicted demand- $\mathrm{ACH}$ rate proposed for each model-was used to determine the variations in cooling/heating loads and the predictions for different leakage values. That procedure holds special promise, for it is directly applicable to predict the improvement potential of envelope rehabilitation.

The correlation between leakage rate and energy demand for a given regime need not necessarily be linear but may exhibit a certain tendency to grow asymptotically after a given $\mathrm{ACH}$ value. Nonetheless, in the range normally found in the housing units analysed, it could be likened to a continuous linear relationship. In other words, for the values routinely observed in building stocks, the relationship between infiltration and demand can be fitted to a regression line. The slope on that line is indicative of the relationship between the mean air exchange rate and the expected energy demand, while the other components affecting demand are represented by the constant in the equation. The slopes calculated by simulating housing heating and cooling demand for air changes rate per hour (ACH) of $0.35 \mathrm{~h}^{-1}$ and $0.55 \mathrm{~h}^{-1}$ are discussed below.

The slope values found for infiltration and associated demand leakage rate curves are shown in Figure 5 for the five climate zones analysed. The slopes were flatter in climates with less severe (zone A) and steeper in those with more severe (zone C) winters. The moderate slopes observed for 
zones A3 (15.97) and A4 (14.08) were an indication that the energy demand in those areas would be less affected by changes in infiltration rate. In contrast, with a slope of 37.23 and a much wider standard deviation, the climate zone $\mathrm{C} 3$ sample would be more sensitive to wintertime leakage.

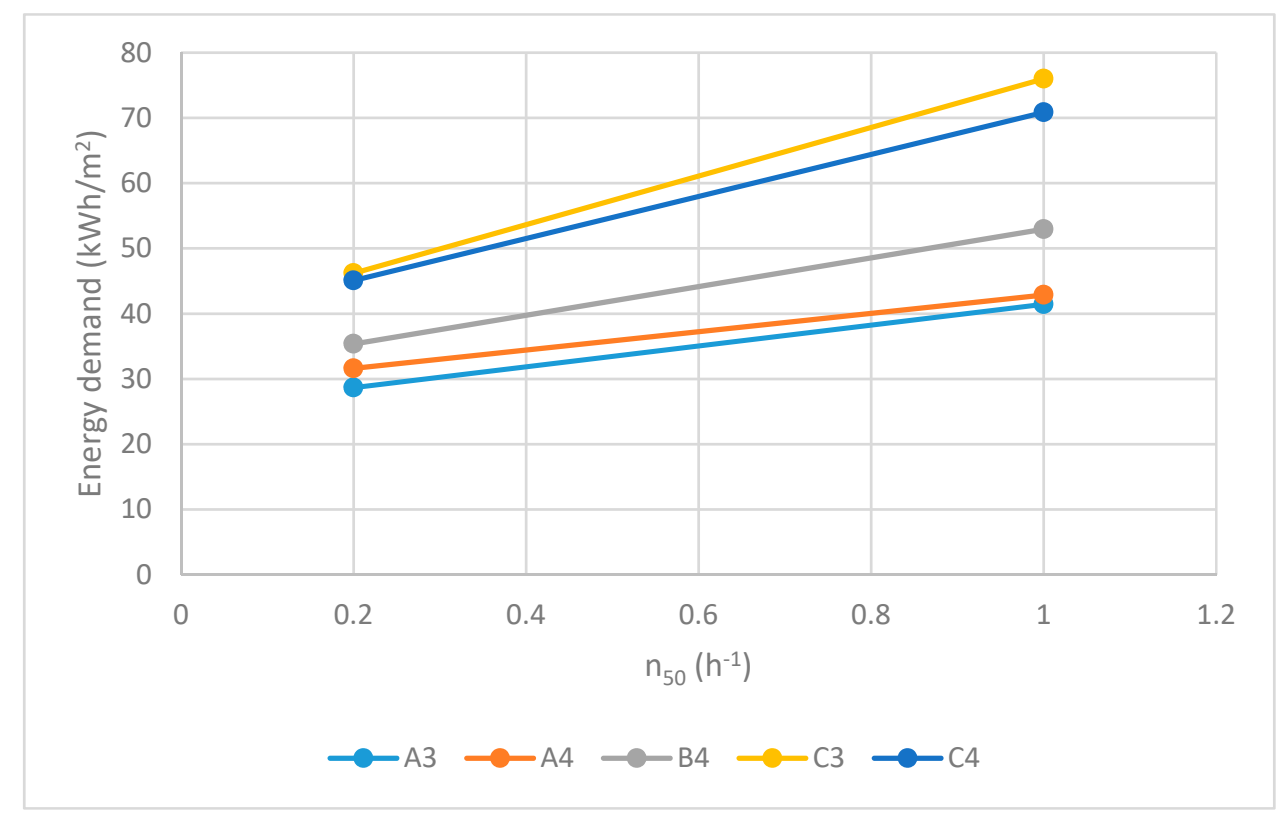

Figure 5. Energy demand vs $\mathrm{n}_{50}$ for five climate zones.

The values published for a similar study on detached housing in Finland [41,42] were higher due to the difference in climate. In this study, with $\mathrm{ACH}$ values at around $0.35 \mathrm{~h}^{-1}$, the energy demand ranged from $30 \mathrm{kWh} / \mathrm{m}^{2}$ to $51 \mathrm{kWh} / \mathrm{m}^{2}$ compared to $135 \mathrm{kWh} / \mathrm{m}^{2}$ to $195 \mathrm{kWh} / \mathrm{m}^{2}$ in Finland.

\subsection{Predicted Proportion of Demand Attributable to Air Leakage}

The model results for mean yearly energy demand attributable to leakage and its relationship to total demand for the climate zones studied, assuming an $\mathrm{ACH}$ of $0.35 \mathrm{~h}^{-1}$, are shown in Figure 6.

As in the other values analysed, the peak was observed in climate zone $\mathrm{C} 3$, where leakage would account for an annual demand in the order of $13 \mathrm{kWh} / \mathrm{m}^{2}$ or $25 \%$ of the total. The lowest values, in turn, were again found for climate zones A3 (with $5.59 \mathrm{kWh} / \mathrm{m}^{2}$ and $18 \%$ of the total) and A4 (with $4.93 \mathrm{kWh} / \mathrm{m}^{2}$ and $15 \%$ of the total).

Equation (8) is established to predict energy demand for different leakage rates in the building types analysed, delivers a rough estimate for the building stock in the Mediterranean area. The slope, coefficient and standard deviation values are listed in Table 6.

$$
D_{T O T}=m \cdot \frac{V_{50}}{20 \cdot V}+\alpha
$$

where

$D_{\text {TOT }}$ is the total energy demand $\left(\mathrm{kWh} / \mathrm{m}^{2}\right)$;

$\mathrm{m}$ is the slope (value in Table 6);

$V$ is the internal air volume $\left(\mathrm{m}^{3}\right)$;

$V_{50}$ is the air leakage rate at $50 \mathrm{~Pa}\left(\mathrm{~m}^{3} / \mathrm{h}\right)$;

$\alpha$ in the constant (value in Table 6). 


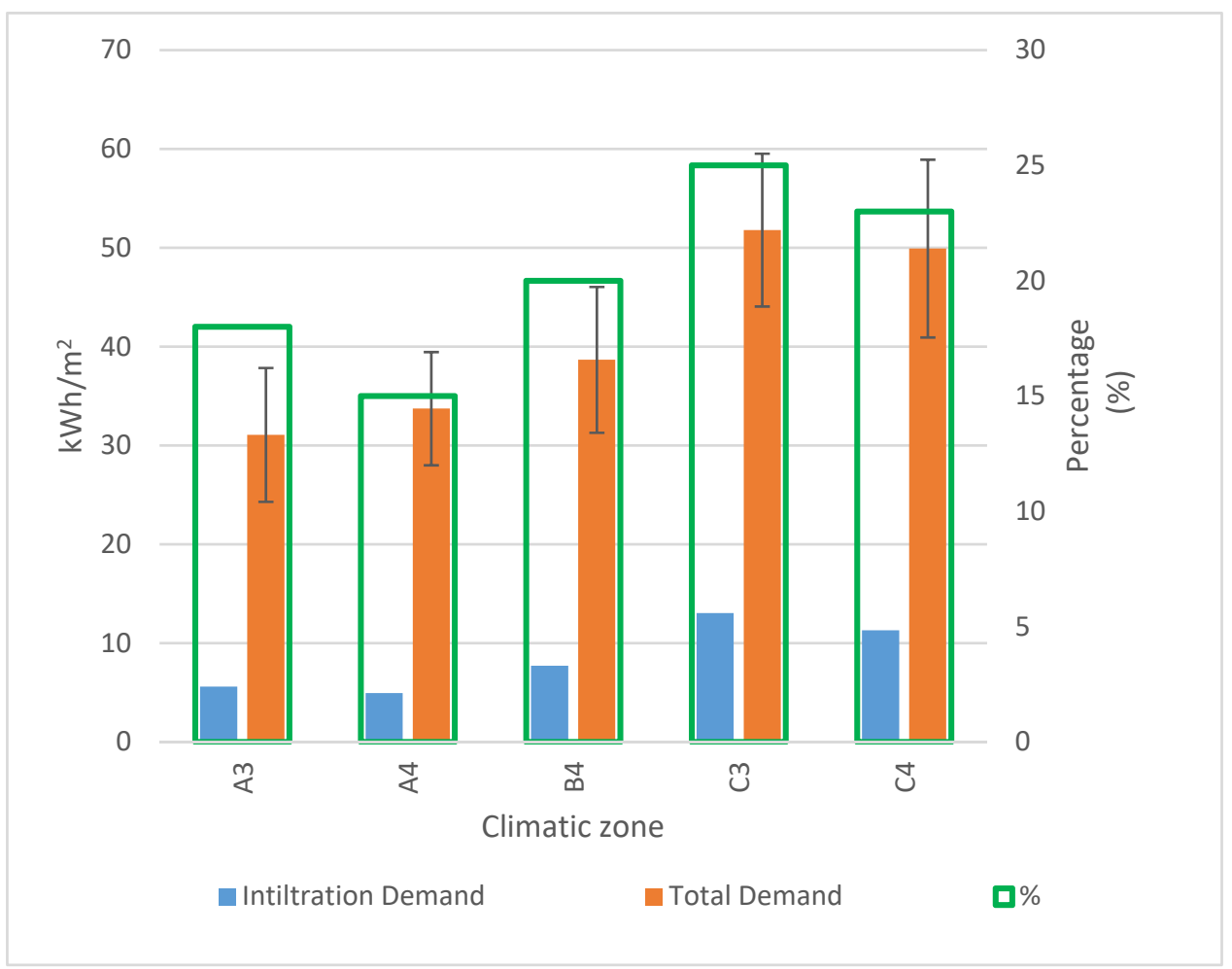

Figure 6. Mean yearly infiltration-induced energy demand (for $\mathrm{ACH}=0.35 \mathrm{~h}^{-1}$ ), yearly mean total demand, percentage of leakage-induced relative to total demand and standard deviation for total demand by climate zone.

Table 6. Equation (8) parameters used to predict total energy demand from the air leakage rate by climate zone.

\begin{tabular}{ccccc}
\hline Climate Zone & Slope $(\mathbf{m})$ & Coeff. $(\boldsymbol{\alpha})$ & SD $_{\mathbf{m}}$ & SD $_{\boldsymbol{\alpha}}$ \\
\hline A3 & 15.97 & 25.47 & 1.9 & 6.1 \\
A4 & 14.08 & 28.79 & 1.1 & 5.3 \\
B4 & 21.97 & 30.97 & 2.0 & 6.8 \\
C3 & 37.23 & 38.76 & 4.5 & 9.1 \\
C4 & 32.21 & 38.64 & 2.1 & 8.3 \\
\hline
\end{tabular}

This model is valid for social, multi-family housing in climate zones A3, A4, B4, C3 and C4 constructed in 1939-1979. The standard deviation for the slope ranged from $6.5 \%$ to $12.1 \%$ of the mean, with the highest value observed in climate zone C3 where the highest wintertime demand was also recorded. While the highest absolute standard deviation for the constant was also highest for zone $\mathrm{C}$, the percentage values relative to the mean (18.3\% to $23.9 \%)$ were in line with those of the other zones, inasmuch as total demand was higher.

\section{Conclusions}

In this study, airtightness categories were defined by determining and statistically analysing the most prominent variables to establish energy scenarios based on the degree of airtightness in the existing housing stock. The simulations showed building envelope airtightness to be linearly correlated to energy demand at typical $n_{50}$ values.

They further showed that the correlation between the two parameters followed a similar pattern in all the developments within each climate zone characterised by the same winter severity $(A, B$ or $C)$ because wintertime air permeability was the factor with the greatest impact on energy demand. Its effect was particularly significant in the most severe climates where it was predicted to account for 
upward of $10 \mathrm{kWh} / \mathrm{m}^{2}$, although values of $>5 \mathrm{kWh} / \mathrm{m}^{2}$ were observed in more temperate zones such as $\mathrm{A} 3$.

The inference is that infiltration induced $15 \%$ to $25 \%\left(\mathrm{ACH}=0.35 \mathrm{~h}^{-1}\right)$ of the heating energy demand in typical social housing built prior to Spain's earliest legislation on building airtightness. In most of the climate zones studied, improving envelope airtightness would translate into a mean potential decline in energy demand of $5 \%$ per $0.1 \mathrm{~h}^{-1}$ reduction in the air change rate per hour $(\mathrm{ACH})$, with values of up to $7.2 \%$ in the colder areas.

The simulated results delivered by the simplified model described can be used to predict energy demand for the existing housing stock from airtightness values. These parameters should not be interpreted to be constant, however, for airtightness is a variable and, in most cases, a degenerative process. Since much of the housing built to lower standards in the residential stock constituting the population studied here is near obsolescence, identifying the units with the highest potential for alteration of their energy balance due to a decline in envelope quality is particularly appropriate.

Author Contributions: Conceptualization, J.F.-A.; Data curation, J.F.-A., S.D.-A., I.A. and M.Á.C.; Formal analysis, S.D.-A., J.F.-A., I.A. and M.Á.C.; Investigation, S.D.-A., J.F.-A., I.A. and M.Á.C.; Methodology, J.F.-A.; Writing—original draft, S.D.-A., J.F.-A., I.A. and M.Á.C.; Writing—review \& editing, S.D.-A., J.F.-A., I.A. and M.Á.C.

Funding: This study was funded by the Spanish Ministry of Economy and Competitiveness under project BIA2012-39020-C02-01, BIA2017-86997-R and the second author benefited from predoctoral contract BES-2013-063097.

Conflicts of Interest: The authors declare no conflict of interest.

\section{References}

1. Healy, J. Housing, Fuel Poverty and Health: A Pan-European Analysis; Routledge: Abingdon, UK, 2017.

2. Gillott, M.; Loveday, D.; White, J.; Wood, C.; Chmutina, K.; Vadodaria, K.; Wood, C. Improving the airtightness in an existing UK dwelling: The challenges, the measures and their effectiveness. Build. Environ. 2016, 95, 227-239. [CrossRef]

3. Johnston, D.; Wingfield, J.; Miles-Shenton, D.; Bell, M. Airtightness of UK Dwellings: Some Recent Measurements. In Proceedings of the RICS Foundation Construction and Building Research Conference, London, UK, 7-8 September 2004.

4. Vinha, J.; Manelius, E.; Korpi, M.; Salminen, K.; Kurnitski, J.; Kiviste, M.; Laukkarinen, A. Airtightness of residential buildings in Finland. Build. Environ. 2015, 93, 128-140. [CrossRef]

5. Paap, L.; Mikola, A.; Teet-Andrus, K.; Kalamees, T. Airtightness and Ventilation of new Estonian Apartments Constructed 2001-2010. In Proceedings of the 33nd AIVC Conference: Optimising Ventilative Cooling and Airtightness for [Nearly] Zero-Energy Buildings, IAQ and Comfort, Copenhagen, Denmark, 10-11 October 2012.

6. Caillou, S.; van Orshoven, D. Report on the building airtightness measurement method in European countries. In ASIEPI: Intelligent Energy Europe; Belgian Building Research Institute: Bruxelles, Belgium, 2010.

7. Chan, W.R.; Joh, J.; Sherman, M.H. Air Leakage of US Homes: Regression Analysis and Improvements from Retrofit. In Proceedings of the 33nd AIVC Conference: Optimising Ventilative Cooling and Airtightness for [Nearly] Zero-Energy Buildings, IAQ and Comfort, Copenhagen, Denmark, 10-11 October 2012; pp. 35-39.

8. Walker, I.; Sherman, M.; Joh, J.; Chan, W.R. Applying Large Datasets toDeveloping a Better Understanding of Air Leakage Measurement in Homes. Int. J. Vent. 2013, 11, 323-338. [CrossRef]

9. Chan, W.R.; Joh, J.; Sherman, M.H. Analysis of air leakage measurements of US houses. Energy Build. 2013, 66, 616-625. [CrossRef]

10. Fernández-Agüera, J.; Domínguez-Amarillo, S.; Sendra, J.J.; Suárez, R. An approach to modelling envelope airtightness in multi-family social housing in Mediterranean Europe based on the situation in Spain. Energy Build. 2016, 128, 236-253. [CrossRef]

11. Fernández-Agüera, J.; Salas, J.J.S.; Medina, R.S.; Domínguez-Amarillo, S. Airtightness and Indoor Air Quality in Subsidised Housing in Spain. In Proceedings of the 35th AIVC Conference "Ventilation and Airtightness in Transforming the Building Stock to High Performance", Poznań, Poland, 24-25 September 2014. 
12. Fernández-Agüera, J.; Sendra, J.J.; Domínguez, S.; Domínguez-Amarillo, S. Protocols for Measuring the Airtightness of Multi-Dwelling Units in Southern Europe. Procedia Eng. 2011, 21, 98-105. [CrossRef]

13. Jesús, F.; Irene, P.; Alonso, G.R.; Cristina, P.; Víctor, E.; Rafael, A.; Jesica, F.; Jesús, D.M.; José, V.; Manuel, M.C.; et al. Methodology for the Study of the Envelope Airtightness of Residential Buildings in Spain: A Case Study. Energies 2018, 11, 704. [CrossRef]

14. Tiberio, A.J.; Branchi, P. A study of air leakage in residential buildings. In Proceedings of the 2013 International Conference on New Concepts in Smart Cities: Fostering Public and Private Alliances (SmartMILE), Gijon, Spain, 11-13 December 2013; pp. 1-4.

15. Infiles Project. Available online: Infiles.uva.es/ (accessed on 27 March 2019).

16. Sfakianaki, A.; Pavlou, K.; Santamouris, M.; Livada, I.; Assimakopoulos, M.-N.; Mantas, P.; Christakopoulos, A. Air tightness measurements of residential houses in Athens, Greece. Build. Environ. 2008, 43, $398-405$. [CrossRef]

17. Alfano, D.F.R.; Dell'Isola, M.; Ficco, G.; Tassini, F. Experimental analysis of air tightness in Mediterranean buildings using the fan pressurization method. Build. Environ. 2012, 53, 16-25. [CrossRef]

18. Alves, S.; Fernández-Agüera, J.; Sendra, J.J. Infiltration rate performance of buildings in the historic centre of Oporto. Inf. Construcción 2014, 66, e033. [CrossRef]

19. Pereira, P.F.; Almeida, R.M.S.F.; Ramos, N.M.M.; Sousa, R. Testing for building components contribution to airtightness assessment. In Proceedings of the 35th AIVC Conference "Ventilation and Airtightness in Transforming the Building Stock to High Performance", Poznań, Poland, 24-25 September 2014; pp. 322-330.

20. Ramos, N.M.M.; Almeida, R.M.; Curado, A.; Pereira, P.F.; Manuel, S.; Maia, J. Airtightness and ventilation in a mild climate country rehabilitated social housing buildings-What users want and what they get. Build. Environ. 2015, 92, 97-110. [CrossRef]

21. Spiekman, M. The Final Recommendations of the ASIEPI Project: How to Make EPB-Regulations More Effective? Belgian Building Research Institute: Bruxelles, Belgium, 2010.

22. Feijó-Muñoz, J.; Pardal, C.; Echarri, V.; Fernández-Agüera, J.; De Larriva, R.A.; Calderín, M.M.; Poza-Casado, I.; Padilla-Marcos, M.Á.; Meiss, A.; Jesús, F.-M.; et al. Energy impact of the air infiltration in residential buildings in the Mediterranean area of Spain and the Canary islands. Energy Build. 2019, 226-238.

23. Meiss, A.; Feijó-Muñoz, J. The energy impact of infiltration: A study on buildings located in north central Spain. Energy Effic. 2014, 8, 51-64. [CrossRef]

24. Presidencia del Gobierno. Real Decreto 2429/1979, de 6 de julio, por el que se aprueba la norma básica de edificación NBE-CT-79, sobre condiciones térmicas en los edificios. Boletín Oficial del Estado; Gobierno de España: Madrid, Spain, 1979.

25. Ministerio de Fomento del Gobierno de España, Código técnico de la Edificación (CTE), Spain. 2017. (In Spanish). Available online: https://www.codigotecnico.org/ (accessed on 20 March 2019).

26. Dubrul, C. Technical Nte AIVC 23. Inhabitant Behaviour with Respect to Ventilation-A Summary Report of IEA Annex VIII; 1988. Available online: https://www.aivc.org/resource/tn-23-inhabitant-behaviour-respectventilation-summary-report-iea-annex-viii (accessed on 20 March 2019).

27. Ferrara, M.; Monetti, V.; Fabrizio, E. Cost-Optimal Analysis for Nearly Zero Energy Buildings Design and Optimization: A Critical Review. Energies 2018, 11, 1478. [CrossRef]

28. Domínguez, S.; Sendra, J.J.; León, A.L.; Esquivias, P.M.; Domínguez-Amarillo, S.; Leon-Rodriguez, A.L. Towards Energy Demand Reduction in Social Housing Buildings: Envelope System Optimization Strategies. Energies 2012, 5, 2263-2287. [CrossRef]

29. Domínguez-Amarillo, S.; Sendra, J.J.; José, I.O.S. La Envolvente Térmica de la Vivienda Social: El Caso de Sevilla, 1939 a 1979 Title, 1st ed.; Editorial Consejo Superior de Investigaciones Científicas: Madrid, Spain, 2016.

30. Domínguez-Amarillo, S.; Sendra, J.J.; Fernández-Agüera, J.; Escandón, R. La construcción de la vivienda social en Sevilla y su catalogación 1939-1979; Universidad de Sevilla: Sevilla, Spain, 2017.

31. Chan, W.R.; Nazaroff, W.W.; Price, P.N.; Sohn, M.D.; Gadgil, A.J. Analyzing a database of residential air leakage in the United States. Atmos. Environ. 2005, 39, 3445-3455. [CrossRef]

32. De La Flor, F.J.S.; Domínguez, S.Á.; Félix, J.L.M.; Falcón, R.G. Climatic zoning and its application to Spanish building energy performance regulations. Energy Build. 2008, 40, 1984-1990. [CrossRef]

33. CEN. Thermal Performance of Buildings_-Determination of Air Permeability of Buildings_Fan Pressurization Method; ISO: Geneva, Switzerland, 2015. 
34. Fernández-Agüera, J.; Domínguez-Amarillo, S.; Sendra, J.J.; Suárez, R.; Oteiza, I. Social housing airtightness in Southern Europe. Energy Build. 2019, 183, 377-391. [CrossRef]

35. Persily, A.K.; Axley, J. Measuring Airflow Rates with Pulse Tracer Techniques. In STP1067-EB Air Change Rate and Airtightness in Buildings; ASTM International: West Conshohocken, PA, USA, 1990; pp. 31-51.

36. Sherman, M.H. Estimation of infiltration from leakage and climate indicators. Energy Build. 1987, 10, 81-86. [CrossRef]

37. EN 12831:2017. Energy Performance of Buildings. Method for Calculation of the Design Heat Load. Space Heating Load, Module M3-3; BSI: London, UK, 2017.

38. Domínguez-Amarillo, S.; Fernández-Agüera, J.; Sendra, J.J.; Roaf, S. Rethinking User Behaviour Comfort Patterns in the South of Spain-What Users Really Do. Sustainability 2018, 10, 4448. [CrossRef]

39. Ashrae. Ashrae Guide and Data Book (Fundamentals); Ashrae: Atlanta, GA, USA, 2002; p. 148.

40. Raftery, P.; Keane, M.; Costa, A. Calibrating whole building energy models: Detailed case study using hourly measured data. Energy Build. 2011, 43, 3666-3679. [CrossRef]

41. Jokisalo, J.; Kurnitski, J.; Korpi, M.; Kalamees, T.; Vinha, J. Building leakage, infiltration, and energy performance analyses for Finnish detached houses. Build. Environ. 2009, 44, 377-387. [CrossRef]

42. Kalamees, T.; Kurnitski, J.; Eskola, L.; Jokiranta, K.; Vinha, J.; Jokisalo, J. A Comparison of Measured and Simulated Air Pressure Conditions of a Detached House in a Cold Climate. J. Build. Phys. 2008, 32, 67-89.

(C) 2019 by the authors. Licensee MDPI, Basel, Switzerland. This article is an open access article distributed under the terms and conditions of the Creative Commons Attribution (CC BY) license (http://creativecommons.org/licenses/by/4.0/). 